\title{
Students and Teachers' Perceptions of the Most Valued Teaching Actions
}

\author{
By Carlos Iberico* \\ Julio Del Valle \\ Maria Angélica Pease
}

The aim of this study was to identify and describe students and teachers' perceptions on the most valued teaching actions in order to learn. Two samples were used for this study: 352 university teachers and 2634 undergraduate students answered to a questionnaire on different teaching actions. Results showed that teaching actions assessed in the questionnaire were considered important by both samples, since they favor students' learning. Teachers considered as the most valued actions presenting the class topic and linking it with reality using examples, asking questions to students to make them participate or identifying if they understood the topic and clarifying doubts. On the other hand, students gave a similar appraisal but with significantly lower scores. Some new research lines are suggested such as teachers' beliefs on learning and assessment in higher education.

Keywords: assessment, class development, higher education, teaching actions

\section{Introduction}

The new demands of the modern world, caused by the knowledge society and the use of information and communication technology, as well as the massification of higher education, and the high degree of competition among university institutions, have emphasized the importance of the quality of the teaching practices offered (Fitzmaurice, 2010). For that reason, there is a large number of papers focused on investigating the teaching quality, the effectiveness of different teaching practices and the ways they can be measured (Alderman, 2007; Bain, 2004; Hernández Méndez, Mijangos, \& Malpica, 2011). Consequently, the proper use of different teaching practices in higher education determines the achievement of the learning outcomes (Zabalza, 2012). In that regard, to carry out an appropriate research on teaching practices, it is necessary to define them.

First of all, practice is defined as "the unique way in which a teacher does

\footnotetext{
${ }^{*}$ Head of the Research Area, Institute of University Teaching, Pontifical Catholic University of Peru, Peru.

${ }^{\dagger}$ Director, Institute of University Teaching, Pontifical Catholic University of Peru, Peru.

* Associate Professor, Department of Psychology, Pontifical Catholic University of Peru, Peru.
} 
things, this consists of not only observable actions but also the choice of specific situations and decision making" (Altet cited in Perez, Sarmiento, \& Zabalza, 2012, p. 147). Thus, a teaching practice is conceived as an array of situations in the classroom that shape the teacher and students' performance, according to certain objectives and is confined to a set of actions that directly affect students' learning (García-Cabrero, Loredo, \& Carranza, 2008; Martínez-Rizo, 2012).

As stated above, teaching practice is a concept usually applied in a classroom context. However, there are many variables outside the class (such as teaching planning, assessment tools and communication) that affect the teaching-learning process. For that reason, it was decided to use a more general concept (teaching action) to be able to analyze the complete process. Therefore, the teaching practices are set by the combination of a group of teaching actions. Nevertheless, teaching actions are not dependent on a classroom context but can be used in different spaces (García-Cabrero, Loredo, \& Carranza, 2008).

The different actions that teachers perform can be classified under different paradigms. Mostly, it is possible to identify two models: one focused on teaching (or teacher-centered) and another focused on learning (or studentcentered) (Biggs, 2006; Gargallo, 2008; Samuelowicz \& Bain, 2001). The former is characterized by content transmission from the teacher to the student. Within this framework, variations in students' learning are attributed to individual differences, such as skills, motivation, school of origin, among others (Biggs \& Tang, 2007). On the other hand, the second model is closely related to the constructivist approach. According to this model, learning is focused on how students create and actively build knowledge from experiences (Seifert \& Sutton, 2009). This kind of classification emphasizes the differences between those conceptions of teaching and polarizes them to explain what teaching actions can be better to achieve learning (student-oriented) and what actions not (teacher-oriented) (Towers \& Proulx, 2013).

However, teaching actions are not always so easily to classify in one paradigm. Moreover, valued university teachers tend to manage combined styles (Feixas, 2010). For example, the Oviedo University (2006) found that most valued teachers frequently use lectures to transmit information to students (teacher-oriented) and they can also make the students participate and debate in groups (student-oriented). On the other hand, Becerra and La Serna (2009) interviewed top rated teachers of a private university in Peru in order to know their characteristics. Top rated teachers mentioned that they have been positively inspired by their university teachers or close relatives who have been teachers too and tend to apply and adapt their teaching practices. Besides, they indicated that having life experiences allowed them to develop their didactic skills and share these experiences with their students. Finally, they could plan their classes and employ lectures, but at the same time they encouraged participation and complemented their classes with additional material and resources. In other words, a teacher can use actions focused on both paradigms and be able to generate learning on students. 
After all, the relevance of a teaching action is not established by the practice itself, but in terms of its effectiveness in the learning process. As Zabalza (2012) points out, different educational contexts require different actions. For example, it would be better teaching actions oriented to guide and supervise the students all the time at the beginning of their careers, so that later when students advance in their studies, participation and control of their own learning can be more focused on themselves (Zabalza, 2011).

In that case, instead of asking about what the best teaching actions in higher education are, it is necessary to answer a previous question: what are the teaching actions that are being used by higher education teachers? With this information, a hierarchy of the most valued teaching actions can be established. Hence, the purpose of this research study is not learning, but the value of teaching actions to promote learning. As noted by Biggs and Tang (2007), good teaching actions are those that lead to achieve the expected learning goals.

The most common areas examined when observing teaching actions are: class planning; methodological structuring of teaching content; teacher-student interactions related to academic activities; assessment procedures implemented; the organization of the classroom activities and the different kinds of academic tasks (De Vicenzi, 2009). However, there are no studies about this topic in our national context. For this reason, it is important to develop a classification that can be applied in our country.

In that regard, the aim of this study was to examine students and teachers' perceptions of the most valued teaching actions according to how important they are in order to learn. Additionally, a secondary objective was to compare teachers and students' perceptions. This study is important because it is the first attempt to identify and describe the teaching actions at the Pontifical Catholic University of Peru (PUCP). It is a research study open to criticisms or modifications, but it is also the first step in order to optimize teaching action so as to obtain significant and deep learning in students.

\section{Method}

In order to gather information about the most valued teaching actions in the university campus, a descriptive non-experimental design, specifically a survey research, was conducted (Hernández, Fernández, \& Baptista, 2010). The survey was oriented to rate teachers and students' perception about a list of teaching actions. The scope of this survey depends on how the samples scores are accurate enough to describe the population of teachers and students.

\section{Participants}

The sample consisted of 352 teachers and 2634 students during the 2013-2 term (from August to December). 
Regarding the university teachers, it was a non-probability sampling. From a population of 1,533 university teachers, it was planned to have the participation of at least $20 \%$ of them in each Faculty. The participation was voluntary.

With respect to undergraduate students, a representative student sample for each Faculty with a confidence level of $95 \%$ was randomly selected from a total of 131 courses of every academic level (from sophomores to seniors). The distribution of both samples is shown in Table 1.

Table 1. Sample Distribution by Faculty

\begin{tabular}{|c|c|c|c|c|}
\hline \multirow[b]{2}{*}{ Faculty } & \multicolumn{2}{|c|}{ Students } & \multicolumn{2}{|c|}{ Teachers } \\
\hline & $N$ & $n$ & $N$ & $n$ \\
\hline Architecture and Urbanism & 758 & 270 & 86 & 19 \\
\hline Art & 656 & 112 & 98 & 20 \\
\hline Performing Arts & $----*$ & ----* & 46 & 10 \\
\hline Accounting Sciences & 185 & 167 & 29 & 10 \\
\hline Sciences and Engineering & 3281 & 197 & 348 & 74 \\
\hline Communication Arts and Sciences & 986 & 214 & 149 & 29 \\
\hline Social Sciences & 727 & 171 & 91 & 22 \\
\hline Law & 1,539 & 285 & 212 & 54 \\
\hline Education & 245 & 95 & 30 & 9 \\
\hline General Science & $3,443 * *$ & 315 & 124 & 27 \\
\hline General Arts & $3,711 * *$ & 404 & 161 & 33 \\
\hline Administration and Executive Management & 1,016 & 182 & 88 & 18 \\
\hline Liberal Arts and Humanities & 894 & 222 & 139 & 27 \\
\hline Total & 10,287 & 2,634 & $\mathbf{1 , 5 3 3}$ & 352 \\
\hline
\end{tabular}

* Students from Performing Arts Faculty were not selected because the Faculty was created after the data collection.

** Admitted students in 2013-2 semester were not selected because it was their first term.

\section{Instrument}

Survey's construction procedure. Because there were no previous questionnaires to inquire about teaching actions in higher education in Peru, an exploratory qualitative phase was carried out to investigate about the teaching actions that occurred in this context. Thus, 8 focus groups with 7 students each 
and 24 interviews with teachers were conducted. Each focus group was conducted with students who were enrolled at least in the second year of college. In the case of the interviews, two active teachers (teaching in the current academic year) were randomly selected from each faculty.

The categories generated from the qualitative analysis allowed organizing the most common teaching actions in the campus. For each category, a set of items was elaborated and reviewed by a group of experts to ensure the content validity. This course of action improved the comprehension for each item.

Survey's characteristics. The final questionnaire had a total of 75 items. Each item represented a teaching action and participants (university teachers and students) were asked to rate how important they considered each action to promote learning in a Likert scale from 1 (not important) to 10 (very important).

The 75 questions were divided in three areas:

- Development of the class: It is the way teachers perform actions in the classroom. It involves procedures, activities and strategies used to ensure students' learning achievement. The development of the class has three parts: beginning of the class, middle of the class and end of the class.

- Assessment: It refers to the knowledge of the teacher about how to assess, assessment criteria and when and why they use different types of assessment tools. The assessment includes the gathering and analysis of information and students' learning process in order to make decisions.

- Out-of-class communication: It implies the interaction between teachers and students outside the classroom context in order to ensure students' learning achievement.

\section{Procedure and Data Analysis}

Data collection from university teachers was based on an online questionnaire during the 2013-2 term (August to December). Through this via, 282 questionnaires were collected, a number lower than expected. Therefore, the rest of missing teachers were surveyed personally. Data collection from students was based on a face-to-face administration of the questionnaire in their classrooms during the 2013-2 term (August to December).

The Statistical Package for Social Sciences (SPSS, version 22) was used. Teachers and students' means for every action were contrasted. Comparisons were made using the $\mathrm{t}$-student test because the data distribution in both groups (teachers and students) tended to be normal. 


\section{Results}

In most cases, the mean values of these actions were greater than 7 in a 10point scale; hence, most of them were important for both teachers and students in order to promote learning. Though, it is important to observe the appraisal hierarchy of each area.

\section{Beginning of the class}

At the beginning of class (Table 2), both groups (teachers and students) agreed to present the topic of the class and introduce the topic as the most valued of teaching actions. At the same time, both of them situated as the less valued actions: identifying the students' mood for the class and indicating on which unit of the course is the class topic.

Table 2. Means of Teachers and Students' Appraisal about Teaching Actions at the Beginning of the Class

\begin{tabular}{|l|c|c|c|c|c|c|c|}
\hline \multirow{2}{*}{} & \multicolumn{3}{|c|}{ Teachers } & \multicolumn{3}{c|}{ Students } & \\
\cline { 2 - 8 } & $n$ & $M$ & $D . E$ & $n$ & $M$ & $D . E$ & $t$ \\
\hline Presenting the class topic & 340 & $\mathbf{9 . 0 7}$ & 1.53 & 2610 & $\mathbf{8 . 1 6}$ & 1.81 & $10.00^{* *}$ \\
\hline $\begin{array}{l}\text { Presenting the objective of } \\
\text { the class }\end{array}$ & 348 & $\mathbf{8 . 8 1}$ & 1.75 & 2607 & 7.58 & 2.62 & $11.56^{* *}$ \\
\hline $\begin{array}{l}\text { Making an introduction to } \\
\text { the class topic }\end{array}$ & 343 & $\mathbf{8 . 8 0}$ & 1.74 & 2605 & $\mathbf{7 . 9 9}$ & 1.89 & $8.00^{* *}$ \\
\hline $\begin{array}{l}\text { Reviewing the topics of } \\
\text { previous classes }\end{array}$ & 347 & 8.35 & 1.95 & 2609 & 7.49 & 2.00 & $7.50^{* *}$ \\
\hline $\begin{array}{l}\text { Identifying the students } \\
\text { mood for the class }\end{array}$ & 346 & 8.29 & 2.03 & 2600 & 6.79 & 2.35 & $12.69^{* *}$ \\
\hline $\begin{array}{l}\text { Identifying the background } \\
\text { or previous experiences } \\
\text { about the class topic }\end{array}$ & 343 & 8.08 & 2.09 & 2607 & $\mathbf{7 . 6 3}$ & 1.95 & $4.02^{* *}$ \\
\hline $\begin{array}{l}\text { Indicating on which unit of } \\
\text { the course is the class topic }\end{array}$ & 345 & 7.24 & 2.57 & 2594 & 6.68 & 2.41 & $3.87^{* *}$ \\
\hline
\end{tabular}

$* * p<.01$

However, these two groups differed among their highest rated actions; presenting the objective of the class is one of the three highest rated by teachers. On the other hand, identifying the background or previous experiences about the class topic is among the three highest rated actions by students. Finally, teachers rated all these actions significantly higher than students.

\section{Middle of the Class}

In the same way, in the middle of the class (Table 3) linking the class topic with reality using examples is a highly valued action by both samples (teachers and students). 
Table 3. Means of Teachers and Students' Appraisal about Teaching Actions in the Middle of the Class

\begin{tabular}{|l|c|c|c|c|c|c|c|}
\hline \multirow{2}{*}{} & \multicolumn{3}{|c|}{ Teachers } & \multicolumn{3}{|c|}{ Students } & \\
\cline { 2 - 8 } & $n$ & $M$ & $D . E$ & $n$ & $M$ & $D . E$ & $t$ \\
\hline $\begin{array}{l}\text { Providing spaces for students to } \\
\text { participate or ask questions }\end{array}$ & 337 & $\mathbf{9 . 1 5}$ & 1.42 & 2609 & 8.09 & 1.79 & $12.50^{* *}$ \\
\hline $\begin{array}{l}\text { Linking the class topic with reality } \\
\text { using examples }\end{array}$ & 334 & $\mathbf{9 . 1 1}$ & 1.46 & 2598 & $\mathbf{8 . 1 9}$ & 1.86 & $10.43^{* *}$ \\
\hline $\begin{array}{l}\text { Asking questions to identify if students } \\
\text { understand the topic }\end{array}$ & 336 & $\mathbf{9 . 0 4}$ & 1.38 & 2578 & 7.99 & 1.86 & $12.55^{* *}$ \\
\hline Creating spaces of reflection & 339 & 8.94 & 1.46 & 2612 & 7.73 & 1.93 & $13.78^{* *}$ \\
\hline Explaining the class contents & 343 & 8.91 & 1.55 & 2610 & $\mathbf{8 . 2 0}$ & 1.78 & $7.86^{* *}$ \\
\hline $\begin{array}{l}\text { Providing definitions and explanations } \\
\text { of concepts that have been worked. }\end{array}$ & 335 & 8.89 & 1.49 & 2598 & 7.90 & 1.79 & $11.14^{* *}$ \\
\hline $\begin{array}{l}\text { Linking the class topic with } \\
\text { professional or employment situations }\end{array}$ & 338 & 8.84 & 1.79 & 2589 & 7.97 & 2.02 & $8.24 * *$ \\
\hline $\begin{array}{l}\text { Indicating to the students if their work } \\
\text { or advance is good or not and } \\
\text { explaining to them how they could } \\
\text { improve it }\end{array}$ & 337 & 8.64 & 1.84 & 2594 & 8.00 & 2.12 & $5.89^{* *}$ \\
\hline $\begin{array}{l}\text { Suggesting activities for students to } \\
\text { participate in groups }\end{array}$ & 332 & 7.89 & 2.35 & 2609 & 7.27 & 2.28 & $4.65^{* *}$ \\
\hline Providing and solving exercises & 322 & 7.69 & 2.52 & 2610 & $\mathbf{8 . 1 7}$ & 1.85 & $-3.31^{* *}$ \\
\hline
\end{tabular}

$* * p<.01$

Regarding teachers, the actions related to providing spaces for students to participate or ask questions and asking questions to identify if students understand the topic are highly valued by them. On the other hand, the actions of explaining the class contents and providing and solving exercises are the most valued by students. Moreover, the only action that is rated significantly higher by students than by teachers is providing and solving exercises.

\section{At the End of the Class}

Concerning the activities at the end of the class (Table 4), both samples (students and teachers) placed the same actions as the most valued: clarifying doubts, providing guidance related to individual or group assignments done by students and verifying if students have understood the topic developed in class. 
Table 4. Means of Teachers and Students' Appraisal about Teaching Actions at the End of the Class

\begin{tabular}{|l|c|c|c|c|c|c|c|}
\hline \multirow{2}{*}{} & \multicolumn{3}{|c|}{ Teachers } & \multicolumn{3}{c|}{ Students } & \\
\cline { 2 - 9 } & $n$ & $M$ & $D . E$ & $n$ & $M$ & $D . E$ & $t$ \\
\hline Clarifying doubts & 337 & $\mathbf{9 . 3 1}$ & 1.35 & 2593 & $\mathbf{8 . 4 6}$ & 1.75 & $10.46^{* *}$ \\
\hline $\begin{array}{l}\text { Providing guidance related to } \\
\text { individual or group works done by } \\
\text { students }\end{array}$ & 335 & $\mathbf{8 . 7 1}$ & 1.86 & 2605 & $\mathbf{7 . 9 9}$ & 2.10 & $6.58^{* *}$ \\
\hline $\begin{array}{l}\text { Verifying if students have understood } \\
\text { the subject worked in class }\end{array}$ & 337 & $\mathbf{8 . 7 1}$ & 1.74 & 2613 & $\mathbf{7 . 7 0}$ & 2.04 & $9.77^{* *}$ \\
\hline $\begin{array}{l}\text { Mentioning the topic to work in the } \\
\text { next class }\end{array}$ & 337 & 7.89 & 2.21 & 2613 & 7.15 & 2.31 & $5.58^{* *}$ \\
\hline $\begin{array}{l}\text { Making a summary of the subjects } \\
\text { worked in class }\end{array}$ & 336 & 7.88 & 2.21 & 2614 & 7.46 & 2.17 & $3.26^{* *}$ \\
\hline $\begin{array}{l}\text { Making a summary of the subjects } \\
\text { worked in class with the students }\end{array}$ & 337 & 7.42 & 2.40 & 2583 & 7.19 & 2.24 & 1.69 \\
\hline
\end{tabular}
$* * p<.01$

However, the action of making a summary of the topics developed in class with the students had the lowest score in both samples of this area. Statistically significant differences were found in almost all the items, which were more valued by teachers.

\section{Out-of-class Communication}

In the case of out-of-class communication between teacher and students (Table 5), the most valued way of communication is by email. In addition, similarities can be seen in two of the most valued consultation topics by both groups: inquiring about course topics and consulting about research or thesis subjects.

Table 5. Means of Teachers and Students' Appraisal about Teacher-Student Out-Of-Class Communication

\begin{tabular}{|l|c|c|c|c|c|c|c|}
\hline \multirow{2}{*}{ Way of Communication } & \multicolumn{3}{|c|}{ Teachers } & \multicolumn{3}{c|}{ Students } & \\
\cline { 2 - 10 } & $n$ & $M$ & $D . E$ & $N$ & $M$ & $D . E$ & $t$ \\
\hline By email & & & & & & & \\
\hline At teacher's office & 339 & $\mathbf{8 . 3 1}$ & 1.81 & 2611 & $\mathbf{7 . 5 9}$ & 2.22 & $6.73^{* *}$ \\
\hline Subject of Consultation & 322 & 7.39 & 2.69 & 2597 & 6.60 & 2.68 & $4.97^{* *}$ \\
\hline Inquiring about course topics & & & & & & & \\
\hline $\begin{array}{l}\text { Inquiring about research or thesis } \\
\text { subjects }\end{array}$ & 340 & $\mathbf{8 . 9 4}$ & 1.54 & 2607 & $\mathbf{8 . 1 3}$ & 1.96 & $8.71^{* *}$ \\
\hline Inquiring about personal issues & 333 & 7.98 & 2.27 & 2599 & 7.28 & 2.61 & $5.28^{* *}$ \\
\hline$* * p<.01$ & 334 & 6.33 & 2.78 & 2601 & 4.54 & 2.99 & $10.97^{* *}$ \\
\hline
\end{tabular}

On the other hand, inquiring about personal issues is the less valued action 
in this area, and it also has the lowest score of the entire questionnaire, especially by students. Significant differences were found in all the items.

\section{Assessment Criteria}

Regarding to the assessment criteria (Table 6), similarities are observed in the three most valued actions by teachers and students: designing assessments that have the same level of complexity as taught in class, providing students with the assessment criteria so they know how they will be assessed, and having unified assessment criteria between theory and practice.

Table 6. Means of Teachers and Students' Appraisal about Teaching Assessment Criteria

\begin{tabular}{|l|c|c|c|c|c|c|c|}
\hline \multirow{2}{*}{} & \multicolumn{3}{|c|}{ Teachers } & \multicolumn{3}{c|}{ Students } & \\
\cline { 2 - 8 } & $n$ & $M$ & $D . E$ & $n$ & $M$ & $D . E$ & $t$ \\
\hline $\begin{array}{l}\text { Defining the evaluations criteria } \\
\text { before developing assessment tools }\end{array}$ & 337 & $\mathbf{8 . 9 1}$ & 1.63 & -- & -- & -- & -- \\
\hline $\begin{array}{l}\text { Designing assessments that have } \\
\text { the same level of complexity than } \\
\text { taught }\end{array}$ & 334 & $\mathbf{8 . 8 5}$ & 1.65 & 2610 & $\mathbf{8 . 0 9}$ & 2.07 & $7.69^{* *}$ \\
\hline $\begin{array}{l}\text { Providing students with the } \\
\text { evaluation criteria so they will } \\
\text { know how they will be evaluated }\end{array}$ & 338 & $\mathbf{8 . 7 2}$ & 1.80 & 2608 & $\mathbf{8 . 1 6}$ & 2.05 & $5.31^{* *}$ \\
\hline $\begin{array}{l}\text { Having unified evaluation criteria } \\
\text { between theory and practice }\end{array}$ & 329 & $\mathbf{8 . 7 2}$ & 1.70 & 2602 & $\mathbf{8 . 1 3}$ & 1.89 & $5.79^{* *}$ \\
\hline $\begin{array}{l}\text { Providing individual feedback to } \\
\text { students orally }\end{array}$ & 332 & 8.52 & 1.81 & 2613 & 7.88 & 1.94 & $5.68^{* *}$ \\
\hline $\begin{array}{l}\text { Providing general feedback as a } \\
\text { group (resolves exams, works, etc.) }\end{array}$ & 333 & 8.48 & 1.89 & 2610 & 7.73 & 2.26 & $6.68^{* *}$ \\
\hline $\begin{array}{l}\text { Providing written individual } \\
\text { feedback to students }\end{array}$ & 331 & 7.91 & 2.36 & 2606 & 7.68 & 2.07 & 1.70 \\
\hline
\end{tabular}

$* * p<.01$

It should be noted that teachers gave higher scores to all these actions and in most cases, these differences were statistically significant. On the other hand, the actions defining the assessment criteria before developing assessment tools was only asked to teachers for being strictly under their competence.

\section{Assessment Tools}

Finally, with respect to assessment tools (Table 7) teachers and students considered that written tests and the test practice as the two top-rated assessment tools, while quizzes and portfolios are those with lower scores in both groups. In this case, significant differences were only found in expositions and reading comprehension test. Both of them were more valued by teachers. 
Table 7. Means of Teachers and Students' Appraisal about the Assessment Tools

\begin{tabular}{|l|c|c|c|c|c|c|c|}
\hline \multirow{2}{*}{ Written tests } & \multicolumn{3}{|c|}{ Teachers } & \multicolumn{3}{c|}{ Students } & \\
\cline { 2 - 8 } & $n$ & $M$ & $D . E$ & $n$ & $M$ & $D . E$ & $t$ \\
\hline Expositions & 308 & $\mathbf{8 . 4 2}$ & 2.26 & 2552 & $\mathbf{8 . 2 7}$ & 1.90 & -1.16 \\
\hline Test practice & 301 & $\mathbf{8 . 0 9}$ & 2.23 & 2346 & 7.70 & 2.22 & $-2.86^{* *}$ \\
\hline Case solving & 296 & $\mathbf{8 . 0 9}$ & 2.14 & 2453 & $\mathbf{8 . 1 1}$ & 1.91 & 0.12 \\
\hline Exercises & 293 & 8.00 & 2.42 & 2232 & $\mathbf{8 . 0 4}$ & 2.15 & 0.28 \\
\hline Reading comprehension test & 294 & 7.91 & 2.36 & 2276 & $\mathbf{8 . 0 4}$ & 2.13 & 0.87 \\
\hline Written reports & 301 & 7.79 & 2.28 & 2430 & 7.47 & 2.21 & $-2.36^{*}$ \\
\hline Oral tests & 284 & 7.40 & 2.57 & 2254 & 7.19 & 2.39 & -1.31 \\
\hline Essays & 292 & 7.14 & 2.61 & 2251 & 7.08 & 2.50 & -0.40 \\
\hline Monographs & 285 & 7.01 & 2.71 & 2226 & 7.01 & 2.47 & -0.02 \\
\hline Diagrams, concept maps & 283 & 6.99 & 2.65 & 2132 & 6.70 & 2.53 & -1.73 \\
\hline Quizzes & 281 & 6.97 & 2.68 & 2021 & 6.83 & 2.65 & -0.83 \\
\hline Portfolios & 276 & 6.80 & 2.57 & 2077 & 6.91 & 2.51 & 0.73 \\
\hline
\end{tabular}

$* p<.05$

$* * p<.01$

The top-rated scores in written tests are related to the assessment criteria mentioned above. However, it should be noted that students also rank among the top-rated instruments other methods that are not necessarily related to the written tests (case solving and exercises).

\section{Discussion}

The aim of the study was to examine students and teachers' perceptions of the most valued teaching actions according to how important they are in order to learn. The survey based on focus groups and interviews summarized the most commonly used teaching actions in our university.

In general, the results indicated that the teaching actions assessed by teachers and students are considered valuable and important for learning. This is reflected in most of the actions, which were rated between 7 and 10 points on a ten-point scale $(90.7 \%$ of the actions assessed by teachers and $78.7 \%$ of the actions assessed by the students). Furthermore, teachers' ratings were always greater than students' in almost all the actions; this might be explained by a positive self-rating bias since teachers assessed their own performance.

While all actions are perceived as important, when comparing teachers and students' ratings, both groups tended to give a higher score to the actions oriented to present and expose clearly learning objectives and class contents. In addition, other teaching actions related to the constant reflection of what has been learned, the students' participation and the presentation of clear assessment criteria were also positively valued (Oviedo University, 2006). 
Additionally, teachers employed different types of valued actions and not all of them focused on a specific model of teaching. That is, teachers not only used actions related to a lecture style, but they also integrated other kind of teaching actions that may be more related to student's engagement in classroom activities. This would indicate that there are different kinds of valued actions by teachers and not all of them were centered on a specific model of teaching (Feixas, 2010; Gargallo, Fernández, \& Jiménez, 2007).

Regard to each of the areas, actions at the beginning of the class that were top-rated by teachers and students seemed to be more oriented to focus students' attention on the class topic and provide clear initial explanations. This is consistent with the findings in other studies, which confirmed that most valued teachers develop introductions to the topic and their objectives (Perez, Sarmiento, \& Zabalza, 2012).

In the area in the middle of the class, the most valued action by students and teachers was to integrate the classroom knowledge with reality, which may indicate a positive appreciation of teaching actions involving constant reflection about the class topics in both samples. Similarly, teachers considered important an environment in which students could participate in class and propose their own reflections about the class topics. This kind of action is also valued in other studies, where teachers report that their lectures are complemented with different questions to engage students with the class content and provide examples of their own life as an instance of how to apply the class topic in their professional career (Becerra \& La Serna, 2009; Perez, Sarmiento, \& Zabalza, 2012).

However, as in the previous area, there was a special positive appraisal especially in students- of actions aimed to receive information from teachers rather than to participate in class. These results may indicate that the most valued actions by teachers and students can be oriented to different learning objectives and all of them not necessarily fall in the same paradigm (Towers \& Proulx, 2013)

With regard to at the end of the class area, these actions appeared to confirm whether students had managed to understand what was taught in class. Moreover, this was one of the areas where there were more similarities with respect to the hierarchy of actions in both samples.

Similarly to other studies, teaching actions at the end of the class are oriented to summarizing and finishing all the contents that have been developed in the class (Perez, Sarmiento, \& Zabalza, 2012). On the other hand, making a summary together with students was an undervalued action in both groups, probably because this kind of action demanded a greater effort (on one hand, the teacher should manage the students' participation and on the other hand, students must actively participate to have an outcome).

In the area of out-of-class communication, the highest and the lowest scores in both groups supported the conclusion that communication between teacher and student was generally oriented to ask about the topics learned in the course. As a matter of fact, communication outside the class is important to 
engage students with the class content and their own learning (Dobransky \& Frymier, 2004; Nadler \& Nadler, 2000).

However, inquiring about personal issues is one of the least scored actions in all the survey by both groups (teachers and students) despite the fact that trust and intimacy are positively related with learning indicators and motivation in the class (Dobransky \& Frymier, 2004; Jaasma \& Koper, 1999). In this regard, it could be possible that the teachers and students' perception of the teaching-learning process can be directed to knowledge acquisition.

With respect to assessment criteria, both teachers and students indicate that the most valued actions are related to a fair assessment. For example, actions such as defining assessment criteria, having exams or quizzes with the same level of complexity as taught in class and delivering these criteria to students before an assessment are essential for an objective evaluation. Besides, students know in advance how they will be assessed. Becerra and La Serna (2009) found similar results concerning the importance of an impartial and satisfactory evaluation system in a student sample.

In relation to the assessment tools, traditional written instruments were preferred. Nevertheless, the actions related to continuous assessment, in which students were asked to present more elaborated product, were less valued (Samuelowicz \& Bain, 2002).

\section{Limitations}

Regarding limitations of this study, all the teaching actions performed at PUCP were not presented, but those described in the questionnaires. These actions were drawn from interviews and focus groups. In that sense, the questionnaire did not include all the possible actions teachers perform at university, but reflected the most mentioned by both groups (teachers and students). Secondly, a positive bias arising from the responses in the questionnaires should be considered, in which most scores tend to be closer to ten. Additionally, the most or the least valued actions by teachers or students may be influenced by their experience, that is, what actions the student has been exposed to, whether in school or university. Students can only assess what is known for them, in that sense, what is unknown simply does not exist for the student.

\section{Conclusions}

Finally, the different teaching actions included in the survey were highly rated by teachers and students. Additionally, the scores given by both groups have not shown a preference for teaching actions related to a specific teaching model (Feixas, 2010). Likewise, teachers' ratings were greater than students' in almost all the actions because of a self-positive bias. Nevertheless, results confirmed that teaching actions were obtained through interviews and focus 
groups with teachers and students respectively were also valued by a representative sample of the university population.

This is a first attempt to identify and describe teaching actions in our University and it is therefore, a study subject to criticism, improvements or modifications, but it is the initial step in a process of improving teaching actions at PUCP. Additionally, identifying the most valued actions by our teachers and students gradually aim to have a complete mapping of good teaching practices.

Ultimately, new lines of research may be opened from this study. For example, many researchers argue that teachers' beliefs about the learning process of a discipline have an influence in the way they teach (De Vicenzi, 2009; Fry, Ketteridge \& Marshall, 2009). Consequently, it would be appropriate to inquire about the teachers' beliefs about learning and how they may affect their actions. It might also be necessary to explore the assessment processes -either in students or teachers- that are currently handled at our university, in order to have a more reflective and critical approach in relation to these.

As has been found, teachers do not focus on a model but combine both (centered on the teacher or student), it would be interesting to identify when and why they choose to use actions that comprise each of them.

\section{References}

Alderman, L. (2007). Methods research on the evaluation of teaching practice in higher education. In 30th HERDSA Annual Conference, Higher Education Research \& Development Society of Australasia, Adelaide.

Bain, K (2004). What the best College Teachers do. Cambridge: Harvard University Press.

Becerra, A., \& La Serna, K. (2009). Los docentes más valorados por los estudiantes de la UP. ¿Cómo lo logran? [The most valued teachers by UP university. How did they do it?]. Retrieved from http://goo.gl/iXstxp.

Biggs, J. (2006). Calidad del aprendizaje universitario [Teaching for quality learning at University. Buckingham: Open University Press]. Madrid: Narcea.

Biggs, J. \& Tang, C. (2007). Teaching for Quality Learning at University (3rd ed.). London: McGraw Hill.

De Vicenzi, A. (2009). Concepciones de enseñanza y su relación con las prácticas docentes: un estudio con profesores universitarios [Teaching Concepts and Their Relationship to Teaching Practices: A Study with University Professors]. Educación y Educadores, 12(2), 87-101.

Dobransky N., \& Frymier, A. (2004). Developing teacher-student relationships through out of class communication. Communication Quarterly, 52(3), 211223. Retrieved from http://goo.gl/4AliHk.

Feixas, M. (2010). Enfoques y concepciones docentes en la universidad [Teaching Approaches and Conceptions Taken by University Faculty]. RELIEVE, 16(2), 1-27.

Fitzmaurice, M. (2010). Considering teaching in higher education as a practice. 
Teaching in Higher Education, 15(2), 45-55. Retrieved from http://goo.gl/ JogMfO.

Fry, H., Ketteridge, S. \& Marshall, S. (2009). A Handbook for Teaching and Learning in Higher Education Enhancing Academic Practice (3rd ed.). New York: Routledge

García-Cabrero, L., Loredo, J. \& Carranza, G. (2008). Análisis de la práctica educativa de los docentes: pensamiento, interacción y reflexión [Analysis of the Teacher's Educational Practice: Didactic Thinking, Interaction and Reflection]. Revista Electrónica de Investigación Educativa, Especial. Retrieved from http://goo.gl/SoKuuB.

Gargallo, B. (2008). Estilo de docencia y evaluación de los profesores universitarios y su influencia sobre los modos de aprender de sus estudiantes [Teaching and assessment styles of university professors and their influence on the ways of learning of their students]. Revista Española de Pedagogía, 66(241), 425-466.

Gargallo, B., Fernández, A., \& Jiménez, M. (2007) Modelos docentes de los profesores universitarios [Teaching Models of University Professors]. Teoría Educativa, 19, 167-189.

Hernández, R., Fernández, C., \& Baptista, P. (2010) Metodología de la Investigación (5th ed.). [Research Methodology]. Mexico: Mac Graw Hill.

Hernández Méndez, M., Mijangos, J. \& Malpica, S. (2011). Etnografía: su utilidad para estudiar la práctica docente en educación superior [Ethnography: its suitability to study teaching practice in higher education]. Pampedia, 8, 15-25.

Jaasma M. \& Koper R. (1999). The relationship of student-faculty out-of-class communication to instructor immediacy and trust and to student motivation. Communication Education, 48(1), 41-47. Retrieved from http://goo.gl/u6 V861.

Martínez-Rizo, F. (2012). Procedimiento para el estudio sobres las prácticas docentes. Revisión de la literatura [Procedures for studying teaching practices. Literature review]. RELIEVE, 18, 1-22.

Nadler, M., \& Nadler, L. (2000) Out of class communication between faculty and students: A faculty perspective. Communication Studies, 51(2), 176-188. Retrieved from http://goo.gl/jYTww6.

Oviedo University (2006). Análisis de buenas prácticas docentes del profesorado universitario Universidad de Oviedo, Vicerrectorado de Calidad, Planificación e Innovación [Analysis of good teaching practices at university]. Retrieved from https://goo.gl/B8xkd4.

Pérez, A., Sarmiento, J. \& Zabalza, M. (2012). Las prácticas de enseñanza de los mejores profesores de la universidad de Vigo: el ámbito de conocimiento tecnológico [The teaching practices of the good teachers of the Vigo university: the technological area]. Revista de Docencia Universitaria 10(1), 145-175.

Samuelowicz, K. \& Bain, K. (2001). Revisiting academics beliefs about teaching and learning. Kluwer Academic Publisher, 41, 299-325.

Samuelowicz, K., \& Bain, K. (2002). Identifying academics' orientations to assessment practice. Higher Education 43, 173-201.

Seifert, K. \& Sutton, R. (2009). Educational Psychology (2nd ed.). Retrieved from http://goo.gl/smQQST.

Towers, J. \& Proulx, J. (2013). An Enactivist Perspective on Teaching Mathematics: Reconceptualising and Expanding Teaching Actions. Mathematics Teacher Education and Development 15(1), 5-28. 
Zabalza, M. (2011). Metodología docente [Teaching Methodology]. Revista de Docencia Universitaria 9(3), 75-98. Retrieved from http://goo.gl/k1GZQv.

Zabalza, M. (2012). El estudio de las "buenas prácticas" docentes en la enseñanza universitaria [The study of "best teaching practices" in Higher Education]. Revista de Docencia Universitaria 10(1), 17-42. Retrieved from http://goo.gl/ njVYbS. 
